\title{
Section 409A Deferred Compensation Issues For Domestic And International Businesses
}

Martin A. Goldberg, J.D., LL.M., Associate Professor, University of New Haven College of Business, USA Robert E. Wnek, J.D., LL.M., CPA, Professor, University of New Haven College of Business, USA Gregory J. Russo, M.S. in Taxation, CPA, University of New Haven, USA Cynthia Kruth, J.D., Attorney, Fairfield, CT, USA

\begin{abstract}
Internal Revenue Code (the “Code”) $\$ 409$ A creates special rules for nonqualified deferred compensation plans, including discounted stock options, severance arrangement, and even some expense reimbursement arrangements. The primary themes of Section 409A are restrictions that it places upon operation of the deferred compensation plan. In general, it places restrictions on the elections necessary to defer compensation, restrictions on the funding of the plan, and restrictions on the distributions from the plan. If the requirements of Code $\$ 409 A$ and its regulations are not met, all amounts that had been excluded from gross income under the deferred compensation plan are currently included in gross income. Additionally. there is interest due from the original deferral that is one percentage point higher than the regular rate of interest for underpayments, plus a crushing additional 20 percent penalty. ${ }^{l}$ Accordingly it is of paramount importance to understand how these rules apply, and how to avoid the severe penalties.
\end{abstract}

Keywords: Deferred Compensation; Taxation; 409A

\section{INTRODUCTION}

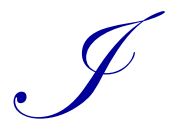

nternal Revenue Code (the "Code") §409A creates special rules and penalties for deferred compensation plans that are not "qualified plans" such as tax-favored pension and profit sharing plans. Code $\$ 409 \mathrm{~A}$ applies to a broad range of deferred compensation arrangements that historically may not have been on the radar of legislators, including discounted stock options, severance arrangements, and even some expense reimbursement arrangements.

Code $\$ 409$ A places restrictions on these types of arrangements that were deferred after December 31, 2004, became vested on of after January 1, 2005, or were materially modified after October 3, 2004. ${ }^{2}$ It places restrictions on the timing of deferral elections, funding of the plan, and the timing and form of distributions from the plan.

Although Code $\$ 409$ A has been effective since 2005, its full force only came into play last year. This is because there have been years of transitional rules, the most recent of which was an extension of time through the end of calendar year 2012 for making corrections to non-conforming plans. ${ }^{3}$

The consequences of noncompliance are significant penalties imposed directly on the executive who received the deferred compensation. There is immediate taxation of all vested deferred compensation. Additionally, there is an interest penalty based upon the underpayment of Federal income taxes that is one percentage point higher than the otherwise-applicable interest rate on underpayments, plus an additional $20 \%$ penalty on the amount included in income.

\footnotetext{
${ }^{1}$ Code $\S 409 \mathrm{~A}(\mathrm{a})$.

${ }^{2}$ IRS Notice 2005-1 Section (I) (E)

${ }^{3}$ IRS Notice 2010-6.
}

Copyright by author(s); CC-BY 


\section{BACKGROUND}

What prompted the changes and how did we get here? The Enron debacle is credited with the sweeping changes that became known as Section 409A. Section 409A is the answer to "pigs get fat and hogs get slaughtered". Therefore, the slaughter occurs at any time during a taxable year a nonqualified deferred compensation plan fails to meet certain requirements. Section 409A targets the individual who earned the deferred compensation, the "service provider," who must immediately recognize as income all compensation deferred under the plan not previously included in gross income, plus the interest and the $20 \%$ penalty tax. ${ }^{4}$

The Enron abuses that ultimately led to Section 409A were deferred compensation plans that were too liberal in permitting executives to accelerate distributions to them of deferred amounts. Permitting easy withdrawal undermined the concept of deferred compensation, and the rationale for deferring taxation. According to the February 2003 Report of the Joint Committee on Taxation, ${ }^{5}$ using a concept similar to a penalty for early withdrawal, called a "Haircut Provision," plan participants were allowed the flexibility to reduce the amount of their distribution by a small percentage, $3 \%$ to $10 \%$. Using this provision, Enron executives received total distributions approximating $\$ 53$ million just weeks prior to the bankruptcy, ${ }^{6}$ "practically transforming many of the plans into taxsheltered checking accounts, in the eyes of critics."

According to The Tax Advisor, the Joint Committee Report indicated "these payouts were part of a much larger program of compensation for top (Enron) management. In 1988, top executives recognized income of approximately $\$ 125$ million from exercising stock options and \$24 million from removing restrictions from stock grants. For 2000 , these numbers were $\$ 1.5$ billion and $\$ 132$ million respectively.",

In the months following Enron's demise, Congress heard extensive testimony outlining deferred compensation arrangements designed to protect the executives and shelter assets in the event of corporate failures. Typical arrangements included financial triggers and offshore trusts in order to reduce risk to the participants. ${ }^{9}$

Section 409A was added to the Code by Section 885 of the American Jobs Creation Act of 2004, Public Law 108-357 (118 Stat. 1418) in October 2004, to combat these and other perceived abuses.

IRS Notice 2005-1 provided what was to be the first part of a series of guidance with respect to the application of $\$ 409 \mathrm{~A}$. Its focus was to generally outline the scope and coverage of the section, providing definitions and transitional relief that permitted modification of plans to comply on a prospective basis. It also gave additional guidance in the form of questions and answers. This notice provided plans must initially come into §409A compliance by December 31, 2005.

The §409A Proposed Regulations were published on September 29, 2005. The proposed rules extended the deadlines for a plan document and good faith compliance and some transitional relief for one year until December 31, 2006. Since the final regulations were still not issued, the IRS extended the deadline through December 31, 2007.

After months of anticipation, the Final Regulations were issued on April 10, 2007, culminating over 2-1/2 years of interim guidance, that became effective on January 1, 2008. Although Final Regulations would ordinarily create some level of certainty in the law, in the case of Code $\$ 409 \mathrm{~A}$ this was only the beginning. Later rulings from

\footnotetext{
${ }^{4} \$ 409 \mathrm{~A}(\mathrm{a})$

5 "Report of Investigation of Enron Corporation and Relate Entities regarding Federal Tax and Compensation Issues and Policy

Recommendations," Joint Committee on Taxation, JCS 3-03 (February 2003), Vol.1. p 12-15.

${ }^{6}$ Stuart R. Singer of Counsel, Jenkins \& Gilchrist, LLP, Los Angeles, CA Deferred Compensation for Executives under Sec. 409A (Part 1), The Tax Advisor, July 2006, by. p. 402.

${ }^{7}$ Theo Francis, Deferred-Pay Rules a Win for Executives; Some Fears Allayed as Treasury Issues Its New Revisions, Wall Street Journal. (Eastern edition) New York, N.Y.: April 11, 2007 pg. D.3.

${ }^{8}$ Stuart R. Singer of Counsel, Jenkins \& Gilchrist, LLP, Los Angeles, CA Deferred Compensation for Executives under Sec. 409A (Part 1), The Tax Advisor, July 2006, by. p 402, Note 2

${ }^{9}$ Theo Francis, Deferred-Pay Rules a Win for Executives; Some Fears Allayed as Treasury Issues Its New Revisions, Wall Street Journal. (Eastern edition) New York, N.Y.: April 11, 2007 pg. D.3.
} 
the IRS, the first wave of court cases, and analysis by tax professionals, have shown that this is an area still greatly in flux. In the meantime, it has had adverse effects on companies, including in some cases transnational business enterprises, raising the question of whether dramatic revision or even repeal would be warranted.

\section{THE MECHANICS OF CODE §409A}

The Code under Section 409A (d)(1) takes a reverse approach to identifying which plans are covered under $\S 409 \mathrm{~A}$. Instead of listing what is specifically included, it defines what is not included. Accordingly, §409A specifically defines the term "nonqualified deferred compensation plan" as any plan that provides for the deferred of compensation other than:

1) A qualified employer plan, such as 401(k) plans, ESOPs and other qualified profit sharing, stock bonus and pension plans qualified under $\$ 401(\mathrm{a})$; and

2) Any bona fide vacation leave, sick leave, compensatory time, disability pay, or death benefit plan."10

\section{What is a Nonqualified Deferred Compensation Plan?}

In general, a nonqualified deferred compensation plan means any plan that obtains a legally binding right to compensation and further provides deferral of that compensation. A deferral of compensation occurs when compensation related to the performance of services is created in one tax year and paid out in a future year. ${ }^{11} \mathrm{~A}$ critical aspect inserted into the Final Regulations included a sentence touted as the "Anti-Abuse Rule:" 12

If a principal purpose of a plan is to achieve a result with respect to a deferral of compensation that is inconsistent with the purposes of Section 409A, the Commissioner may treat the plan as a nonqualified deferred compensation plan for purposes of section 409A. ${ }^{13}$

Accordingly, if the plan satisfies the requirements of $\S 409 A$ the IRS may still reclassify and impose the application of $\S 409 \mathrm{~A}$, which appears to be a "substance over form" issue.

In addition, a theme consistent throughout the Final Regulations has been the Commissioner's use of applying "relevant facts and circumstances" rather than providing relevant examples to explain the application of $\S 409$ A. Hopefully, this will not prove to be as ominous in the future as the Code section itself.

There is also an exception for short-term deferrals. Under this rule, there is not a deferral of compensation if the employee receives the payment within 2-1/2 months after the end of the tax year. For example, if an employee bonus is awarded by a calendar year employer on September 1, and paid by the following March 15, there is no substantial risk of forfeiture, or deferral of compensation, that would be subject to §409A.

A recent court case illustrated some of the applicable issues. In Slater v. Comm' $r^{14}$, the Tax Court examined the question of whether, inter alia, the taxpayer participated in a nonqualified deferred compensation plan under Code $\S 409 \mathrm{~A}$ for commissions to be received as compensation. The court held that, because the taxpayer failed to meet the requirements of $\S 409 \mathrm{~A}(\mathrm{a})(4)$ and the commissions were not subject to a substantial risk of forfeiture, his commissions were included in gross income under Code $\S$ 61(a), 409A(a)(1)(A).

\section{Rules Governing Deferral Elections and Distributions}

The primary themes of Section 409A are the restrictions that it places upon operation of the deferred compensation plan. In general, it places restrictions on the elections necessary to defer compensation, restrictions on the funding of the deferred compensation plan, and restrictions on the distributions of deferred compensation from the plan.

\footnotetext{
${ }^{10} \$ 409 \mathrm{~A}(\mathrm{~d})(1)(\mathrm{A})$ and $(\mathrm{B})$

${ }_{11}^{11} \$ 1.409 \mathrm{~A}-1$ (a) (1) Definitions and covered Plans

${ }^{12}$ Preamble to Final Regulations Section 409A SUPPLEMENTAL INFORMATION Section (II) (D)

${ }_{13}^{13} \$ 1.409 \mathrm{~A}-1$ (a) (1) Definitions and covered Plans

${ }^{14}$ Slater v. Comm'r, T.C. Summary Opinion 2010-1 (January 11, 2010)
} 
The decision for elections and distributions must be made in advance. Once made, the decision cannot be changed except under very limited circumstances. Once again, if the plan is not in compliance, there are significant penalties most notably the $20 \%$ penalty tax imposed on the total deferred compensation amount.

The IRS puffed its chest with the required elections taking away the flexible decision making ability of the service provider to receive income and deduct expenses at a convenient time or event decided by them, such as college funding or the purchase of a second or vacation home.

Initial Deferral Elections: In general, if the service participant would like to defer compensation for services to a future period, the election must be made no later than the close of the taxable year preceding the year the services are to be performed. For example, the service participant election would have to be made by December 31, 2014 for services to be provided in calendar year $2015 .{ }^{15}$ The election must include both the time and form of payment.

If it is the first year that the service participant becomes eligible, then the election does not have to be made until 30 days after the participant becomes eligible to participate in a plan to defer compensation to a future period, for services to be performed subsequent to the election. ${ }^{16}$

For performance-based compensation, the election may be made as late as six months before the end of the relevant 12 -month performance period. ${ }^{17}$

Subsequent changes in time and form of payment (distributions) are permitted only if:

1) The plan requires the change may not take effect until 12 months after the date which the election is made,

2) The first payment under such change must be deferred 5 years from the date it was otherwise to have been made, and

3) The change cannot be made less than 12 months before the first scheduled payment. ${ }^{18}$

\section{Permissible Payments (Distributions)}

The Final Regulations ${ }^{19}$ clarify a single time and form of payment must be designated with respect to each payment event. Except as explicitly provided otherwise, the requirements of $\$ 409 \mathrm{~A}$ are met only if the plan provides that distributions may not be paid earlier than one of the following events: ${ }^{20}$

1) The service provider's separation from service.

2) The service provider becoming disabled.

3) The service provider's death.

4) A time or a fixed schedule specified under the plan.

5) A change in the ownership or effective control of the corporation on in the ownership of a substantial portion of the assets of the corporation.

6) The occurrence of an unforeseeable emergency. ${ }^{21}$

The Final Regulations provide that payments for a fixed date, fixed schedule or on account of a payment event will be treated as made on a timely basis if they are made by the end of the calendar year the event occurs, or, if later, by the $15^{\text {th }}$ day of the third month following the fixed date or due date. For example, where a payment is

\footnotetext{
$15 \$ 409 \mathrm{~A}(\mathrm{a})(4)(\mathrm{B})(\mathrm{i})$

${ }^{16} \$ 409 A$ (a) (4)(B) (ii)

${ }^{17} \$ 409 \mathrm{~A}$ (a) (4)(B) (iii)

${ }^{18} \$ 409 \mathrm{~A}$ (a) (4) (C)

${ }^{19} \$ 1.409 \mathrm{~A}-3$ (a)(1) to (6)

${ }^{20} \$ 409 \mathrm{~A}$ (a) (2)(A) (i) to (vi)

${ }^{21} \$ 409 A$ (a) (2)(A) (i) to (vi)
} 
scheduled to be made upon death of a calendar year service provider, the payment is timely if paid by the later of December 31 of the calendar year the death occurs or the $15^{\text {th }}$ day of the third month following the date of death. ${ }^{22}$

§409A Final Regulations also require a six-month delay for payments to specified employees of a publiclytraded corporation. A specified employee is a "key employee" as defined under the rules applicable to a top heavy qualified plan of a publicly-traded corporation.

\section{Equity-Based Compensation and Incentive Programs}

"It's a good thing" says Martha Stewart and the Martha Stewart Living Executive Bonus Plan further states in the Purpose of the Plan: "The Plan is intended to increase shareholder value and the success of the Company by motivating the Company's key executives (1) to perform to the best of their abilities, and (2) to achieve the Company's objectives. The Plan's goals are to be achieved by providing such executives with incentive awards based upon the achievement of goals relating to the performance of the Company."23

A common method of compensating executives and highly compensated employees (HCEs) of both publicly and private companies is to provide equity-based compensation. Equity-based compensation is a right or privilege granted by the employer corporation to an individual employee that enables the employee to share in the value and/or the growth of the company. Equity-based compensation comes in the form of stock options, stock appreciation rights (SARs), phantom stock units, restricted stock, and deferred bonuses.

As discussed previously, the new §409A requirements do not apply to plans qualified under IRC Section 401(a) which include Employees Stock Option Plans (ESOPs), stock bonus and Incentive Stock Options (ISOs) that satisfy IRC section 422 or options granted under a Section 423 employee stock purchase plan. These plans are already highly regulated and monitored by ERISA for compliance.

\section{Equity Compensation in General}

The legislative history of equity compensation can be very confusing. The issuance of the Final Regulations may appear to have liberalized some of the rules, such as the classification of "service recipient stock." However, the service recipient and the service provider must be aware of the various rules and nuances which can change the character of stock options and stock appreciation rights, which are referred to collectively as "stock rights," or other equity-based compensation, which can trigger $\S 409 \mathrm{~A}$ restrictions and ultimate penalties.

Generally, if a stock right provides a right to receive something other than cash or stock on the date of exercise, such additional right could provide for compensation to be deferred beyond the date of exercise. This could expose the entire arrangement to deferral of compensation and application of $\$ 409 \mathrm{~A}^{24}$

For example, even if a statutory stock option (ISO) is issued at full fair market value, it can be retroactively subject to $\S 409 \mathrm{~A}$ if the exercise period is subsequently modified, extended, or renewed. In such event it would be treated as the grant of a new option, causing the option to have a deferral feature. ${ }^{25}$

Rights to dividend $\mathrm{s}^{26}$ can also present challenges in $\S 409 \mathrm{~A}$. The right to receive dividends between the date of grant and the date of exercise of the stock right may constitute an offset to the exercise price (discount) of the stock option or increase in the amount payable under the SAR. This, too, would generally result in a deferral of compensation causing such stock right to be subject to §409A.

\footnotetext{
${ }^{22} \S 409 \mathrm{~A}-3(\mathrm{~d})$

${ }^{23}$ Excerpt from Martha Stewart Living Omnimedia, Inc. 2002 Performance-Based Executive Bonus Plan.

${ }^{24} \$ 1.409 \mathrm{~A}-1$ (b)(5)(i)(D)

${ }^{25} \$ 1.409 \mathrm{~A}-1(\mathrm{~b})(5)(\mathrm{ii})$

${ }^{26} \$ 1.409 \mathrm{~A}-1$ (b)(5)(i)(E)
} 


\section{Options}

The Final Regulations continue the theme of Notice 2005-1 and the proposed regulations. The employer's grant of nonqualified stock options are exempt from $\S 409$ A when the option to purchase "service recipient stock" does not provide a deferral of compensation. This occurs when:

1. The exercise price is never less than fair market value (not discounted) of the underlying stock on the date of the grant, and the number of shares is fixed on the original date of grant of the option,

2. The transfer or exercise of the options is subject to taxation under $\S 83$, and

3. The option does not include any deferral feature, other than the right to exercise the option in the future. ${ }^{27}$

The Final Regulations, in response to comments to the proposed regulations, relaxed the rules for extensions of stock right exercise periods for executives caught up in a separation of service. Under the proposed regulations, a much shorter period was allowed to extend the exercise period under these circumstances. The new rules provided for a much longer extended period allowing the option or stock right not to be subject to $\$ 409 \mathrm{~A}$, if the extension did not last longer than the original maximum term of the option, or, if shorter, 10 years from the option grant date. ${ }^{28}$

The Final Regulations also provided relief extending the exercise period for options that were considered "under water." This term is used to describe when the fair market value of the underlying stock does not exceed the exercise price. $^{29}$

\section{Stock Appreciation Rights}

The treatment of stock appreciation rights (SARs) is very similar to nonqualified stock options discussed above. The Final Regulations provide similar exemption rules if they are granted as follows:

1. The compensation payable, based on the appreciation, cannot be greater than the excess of fair market value of the stock on the exercise date over the amount specified on the grant date.

2. The exercise price of the SAR may never be less than the fair market value of underlying stock on the grant date; and

3. The SAR does not contain any deferral features other than the SAR. ${ }^{30}$

\section{Requirements for Service Recipient Stock}

The preamble to the Final Regulations explains simply that in order for the exclusion for certain stock rights to apply, "the stock right must relate to service recipient stock". ${ }^{31}$ The Final Regulations further state that service recipient stock, consists of any class of common stock which may be used, subject to limitations on preference distributions, that is common stock for purposes of section 305, regardless of whether another class of common stock that could qualify as service recipient stock is publicly traded or has a higher aggregate value outstanding. ${ }^{32}$

\section{Separation Pay Plans}

Under both the proposed and Final Regulations, separation pay plans are generally treated as deferred compensation subject to $\$ 409 \mathrm{~A}$. However, an exception existed under the proposed regulations for an involuntary separation or participation in a window program. If the separation pay plan was involuntary, the rules were clarified

\footnotetext{
${ }^{27} \S 1.409 \mathrm{~A}-1(\mathrm{~b})(5)(\mathrm{i})(\mathrm{A})$

${ }^{28} \S 1.409 \mathrm{~A}-1(\mathrm{~b})(5)(\mathrm{v})(\mathrm{C})(1)$

${ }^{29} \$ 1.409 \mathrm{~A}-1(\mathrm{~b})(5)(\mathrm{v})(\mathrm{C})(1)$

${ }^{30} \$ 1.409 \mathrm{~A}-1(\mathrm{~b})(5)(\mathrm{i})(\mathrm{B})$

${ }_{31}^{31}$ Preamble to Final Regulations Section (III(D)(3)

${ }^{32} \$ 1.409 \mathrm{~A}-1$ (b)(5)(iii)(A)
} 
and liberalized under the Final Regulations. ${ }^{33}$ Accordingly, involuntary separation pay does not provide a deferral of compensation under $\$ 409 \mathrm{~A}$ if:

1. The separation pay does not exceed two times the lesser of

a. The sum of the service providers annualized compensation, or

b. The maximum amount that may be taken into account under a qualified plan pursuant to $\$ 401(a)(17)$ limit for the year of separation (currently $\$ 260,000$ in 2014), and

2. The plan provides that the separation pay must be paid not later than the last day of the second taxable year of the service provider following the year of separation.

The Final Regulations liberalized this exception from the proposed regulations in two very important ways.

First, under the proposed regulations if the separation pay exceeded the above limits, it appeared that all separation pay was to be treated as deferred compensation under $\$ 409 \mathrm{~A}$. However, under the Final Regulations, only the amounts in excess of the limitations are subject to the requirements under $\$ 409 \mathrm{~A}$. For example, if an employee received $\$ 285,000$, which was greater than the $\$ 401$ (a)(17) limit of $\$ 260,000$ (which was the less than his or her annualized compensation), only the amount in excess of the limit, or $\$ 25,000$, would be subject to $\$ 409 \mathrm{~A}$ deferral elections, distribution rules, and funding requirements.

Second, the proposed regulations limited the exception to an "actual voluntary termination". ${ }^{34}$ The Final Regulations changed this by also allowing separations from service for "good reason". 35 The Final Regulations provide that a service provider's voluntary separation from service will be treated as involuntary separation from service if: ${ }^{36}$

1. The avoidance of $\S 409 \mathrm{~A}$ is not a purpose of the inclusion of these (good reason) conditions in the plan,

2. The good reason condition requires a "material negative change" in the employer/employee relationship, such as reduction in the duties to be performed or reduction in compensation,

3. The extent to which payments are the same as to time and form as would be if an actual involuntary separation occurred, and

4. The employee has an opportunity to remedy the condition that gave rise to the separation.

The Final Regulations also provide a "safe harbor" definition for good reason. If the good reason condition occurs under the following certain express conditions, a separation will be treated as involuntary and not subject to $\S 409 \mathrm{~A}:$

1. The separation from service must occur during a limited time not to exceed two years following the initial existence of one or more of the following conditions:

a. Material diminution in the service provider's base compensation.

b. Material diminution in the service provider's authority, duties, or responsibilities.

c. Material diminution in the authority, duties, or responsibilities of the service provider's supervisor, or the service provider's change in reporting structure.

d. Material diminution in the budget for which the service provider was responsible.

e. A material geographic change in job location.

f. Material breach by service recipient of the employment agreement.

2. The amount, time and form of payment are the same as if an actual involuntary separation from service occurred.

3. The good reason condition must be provided by the service provider to the service recipient and an opportunity to remedy the situation must be made available within certain time frames. ${ }^{37}$

\footnotetext{
${ }^{33} \$ 1.409 \mathrm{~A}-1$ (b)(9)(iii)

${ }^{34}$ Proposed Regulations 1.409A-1(b)(9)(iii)

${ }^{35} 1.409 \mathrm{~A}-1$ (n) (2)

${ }^{36} 1.409 \mathrm{~A}-1$ (n)(2)(i)

${ }^{37} 1.409 \mathrm{~A}-1$ (n)(2)(ii)
} 


\section{Plan}

The Final Regulations define a plan as "any agreement, method, program, or other arrangement...that applies to one person or individual.",38

The establishment of the plan must be in writing, and a plan may fail to be established and maintained if it does not contain the following requirements: ${ }^{39}$

1. Initial deferral election provisions

2. Subsequent deferral election provisions, if permitted

3. Payment accelerations

4. Six-month delay for specified employees

5. Plan amendments

6. Transition rule for written plan amendment

7. Plan aggregation rules

Plan Aggregation Rules: The Final and proposed regulations treat all similar types of plans, or categories, of deferred compensation of a service recipient for a single service provider as a single plan.

The enumerated categories under the proposed regulations included four categories a) amounts deferred under account balance plans, b) amounts deferred under nonaccount balance plans, c) amounts deferred under separation pay plans providing payments due solely due to an involuntary termination or participation in a window program, and d) amounts deferred under any other plan. ${ }^{40}$

The Final Regulations provide additional categories, in addition to the proposed regulations, of plans for purposes of the plan aggregation rules. The new categories include a) split-dollar life insurance, b) reimbursement plans, c) stock rights, d) previously-defined account balance plans which must be subdivided into elective and nonelective plans, and e) any amounts deferred under a foreign plan may be treated as deferred under a separate plan from a domestic plan.

"Expanding the number and type of plan categories has the significant benefit of limiting the impact of failure to comply with $\S 409 \mathrm{~A} .{ }^{41}$ For example, account balance plans were divided into elective and nonelective plan categories, so, a deferral of compensation into each category would constitute separate plans. Any adverse consequences in elective deferral plan, then, would not affect the nonelective deferral plans.

\section{Substantial Risk of Forfeiture}

Compensation is subject to a substantial risk of forfeiture if entitlement to the amount is conditioned on the performance of substantial future services by any person, or on the occurrence of a condition and the possibility of forfeiture is substantial. There can be no guarantee that the compensation will be received.

While this may seem obvious at first glance, the IRS also provides a fact and circumstance approach to determine if the executive controls the deferred compensation, or, if it is truly "at risk," as evidenced by the following examples provided in the Final Regulations:

Example 1. A service provider would be considered as having deferred compensation subject to a substantial risk of forfeiture, but for the fact that the service provider owns 20 percent of the single class of stock in the transferor corporation. If the remaining 80 percent of the class of stock is owned by an unrelated individual (or members of such an individual's family) so that the possibility of the corporation enforcing a restriction on such rights is substantial, then such rights are subject to a substantial risk of forfeiture.

\footnotetext{
${ }^{38} \$ 1.409 \mathrm{~A}-1(\mathrm{c})(1)$

${ }^{39} \$ 1.409 \mathrm{~A}-1(\mathrm{c})(3)(\mathrm{i})$ to (viii)

${ }^{40} \$ 1.409 \mathrm{~A}-1(\mathrm{c})(2)$

${ }^{41} 2007$ Sutherland, Asbill \& Brennan, LLP, Legal Alert: IRS Issues Final Section 409A Regulations, April 13, 2007
} 
Example 2. A service provider would be considered as having deferred compensation subject to a substantial risk of forfeiture. In this case however, the service provider, is president of the corporation, also owns 4 percent of the voting power of all the stock of a corporation. If the remaining stock is so diversely held by the public that the president, in effect, controls the corporation, then the possibility of the corporation enforcing a restriction on the right to deferred compensation of the president is not substantial, and such rights are not subject to a substantial risk of forfeiture. [Emphasis added] ${ }^{\mathbf{4 2}}$

\section{THE CURRENT QUAGMIRE FOR INTERNATIONAL BUSINESSES}

Most of the attention given to Code $\S 409 \mathrm{~A}$ has focused on purely domestic arrangements. However certain transnational arrangements will also be stuck in the quagmire, primarily compensation of U.S. citizens working outside of the U.S., whether or not for a U.S. company. Compensation of resident aliens creates its own special issues.

If an individual is not a U.S. citizen, and has income from a non-U.S. source, then 409A would not apply. However if that individual takes residence in the United States, then a transitional rule would apply. ${ }^{43}$ Under this rule:

If a service provider who was not previously subject to 409A becomes a U.S. resident alien, he or she is given a limited transition period to meet the time and form of payment requirements of 409A with respect to any nonqualified deferred compensation plan covering that service provider. The service provider must elect (or be deemed to have elected) by the end of his or her first taxable year in which he or she is a U.S. resident alien: (i) to defer nonqualified deferred compensation payable for services performed during that first taxable year or (ii) to defer nonqualified deferred compensation payable for services performed in a prior year but still subject to a substantial risk of forfeiture (generally, not yet "vested") as of the first day of that first taxable year. The service provider's deferral election, however, may not apply to compensation that has already been paid or made available to the service provider before the election is made. For example, a service provider who becomes a U.S. resident alien in 2011 has until the end of 2011 to make a deferral election for nonqualified deferred compensation earned during 2011 and for nonqualified deferred compensation that was unvested as of January 1, 2011, but the election can only relate to amounts paid or made available after the election is made. ${ }^{44}$

\section{Impact of §409A on Offshore Trusts:}

As we've seen, above, the impact of $\S 409 \mathrm{~A}$ on Rabbi trusts is vague and undefined. While the implications of this vagueness are ominous, $\S 409 \mathrm{~A}$ specifically makes the taxation of offshore trusts more definitive. Accordingly, contributions to a trust or other arrangement organized outside of the United States for the purposes of paying deferred compensation under a nonqualified deferred compensation plan shall be treated as property transferred in connection with performance of services, ${ }^{45}$ whether or not such assets are available to satisfy claims of general creditors. ${ }^{46}$ Therefore, the transfers are subject to immediate income recognition to the service provider:

1) at the time the assets are set aside (directly or indirectly) in a trust of other arrangement outside of the United States, or

2) at the time assets are transferred, if the trust assets are subsequently transferred outside of the United States $^{47}$

\footnotetext{
${ }^{42} \S 1.409 \mathrm{~A}-1(\mathrm{~d})(3)(\mathrm{ii})$

${ }^{43}$ McKenna, Long, and Aldredge LLP, Companies Should Be Reviewing The Impact of 409A on International Arrangements, http://www.mckennalong.com/news-advisories-2478.html, last retrieved August 6, 2014.

${ }^{44} \mathrm{Id}$.

${ }^{45} \$ 83$

${ }^{46} \$ 409 \mathrm{~A}(\mathrm{~b})(1)$

${ }^{47} \S 409 \mathrm{~A}(\mathrm{~b})$ (1) (A) and (B)
} 
It is important to note, however, these foreign trust rules do not apply to assets located outside of the United States if substantially all the services to which the nonqualified deferred compensation relates are performed in that foreign jurisdiction. ${ }^{48}$

Section 409A (b)(2) further provides that income inclusion is required if assets become restricted upon a change in the employer's financial health, "financial triggers" as of the earlier of:

1) the date on which the plan first provides that assets will become restricted to the provision of benefits under the plan in connection with a change in the employer's financial health, or

2) the date on which assets are so restricted, whether or not such assets are available to satisfy claims of general creditors. ${ }^{49}$

The Code further states that for each taxable year that the assets remain set aside in the offshore trust or other offshore arrangement, any increase in value on such assets will be treated as additional transfers of property. These would then be subject to inclusion in income to the extent not previously included.

In addition, if as of a date on or before December 31, 2007, assets are no longer associated with the payment of nonqualified deferred compensation, either under the terms of the plan or through the dissolution of a trust or desegregation of assets, the plan will be treated as having complied with section 409A (b) with respect to those assets through the date such action is taken. ${ }^{50}$

Internal Revenue Bulletin: 2006-33 provides that "until further guidance is issued, taxpayers may rely upon a reasonable, good faith interpretation of $\S 409 \mathrm{~A}(\mathrm{~b})$ to determine whether the use of a trust or another arrangement causes an amount to be included in income under $\S 409 \mathrm{~A}(\mathrm{~b}) .{ }^{51}$ The Notice further provides special grace period transition relief with a limited period, to December 31, 2007, to come into compliance regarding the application of $\S 409 \mathrm{~A}(\mathrm{~b})$ to nonqualified deferred compensation plans. "This notice is not affected by the Final Regulations". 52

Section 409A(b)(4) provides that in the event amounts are required to be included in income under section $409 \mathrm{~A}(\mathrm{~b})(1)$ (due to use of an offshore trust or similar arrangement) or section 409A(b)(2) (due to a restriction on assets in connection with a change in the financial health of the service recipient), the tax imposed on such inclusion is increased by the sum of the amount equal to $20 \%$ of the amount required to be included in income, plus an interest charge based on the underpayment interest rate plus $1 \%$ determined on the underpayments of tax that would have occurred if the affected deferred amounts had been includible in income for the taxable year when first deferred. ${ }^{53}$

\section{CONCLUSION}

The genesis of Code $\S 409 \mathrm{~A}$ may have been a laudable desire to curtail perceived abuses in the area of deferred compensation planning, both in terms of tax abuses as well as financial reporting abuses. However, there is a vast range of legitimate techniques that are used by employers and employees to provide for compensation, and $\S 409 \mathrm{~A}$ has an impact on virtually all of them. The core problem is that $\$ 409 \mathrm{~A}$ seems to have been called upon to fix problems beyond where problems actually exist, that compensation which ought to be regarded as routine business transactions are scrutinized, and that a wide range of ordinary activity may subject a taxpayer to extraordinary penalties.

\footnotetext{
${ }^{48} \S 409 \mathrm{~A}(\mathrm{~b})(1)(\mathrm{b})$

${ }^{49} \S 409 \mathrm{~A}(\mathrm{~b})(2)$

${ }^{50}$ IRB Notice 2006-33 (III) (A)

${ }^{51}$ IRB Notice 2006-33 (III) (A)

${ }_{53}^{52}$ Preamble to Section 409A Final Regulations - Effect on Other Documents

${ }^{53} \S 409 \mathrm{~A}$ (b) (4) and IRB Notice 2006-33 (II) (A) (4)
} 


\section{AUTHOR INFORMATION}

Martin A. Goldberg is an associate professor at the University of New Haven College of Business, teaching business law and advanced taxation courses. (Martin A. Goldberg is the contact person, and can be reached at mgoldberg@newhaven.edu.)

Robert E. Wnek is a professor at the University of New Haven College of Business. He is the chair of the accounting department, and coordinator of the Masters in Science in Taxation program.

Gregory J. Russo is a certified public accountant with a wide range of experience in accounting and auditing. He received his M.S. in Taxation at the University of New Haven in 2007.

Cynthia Kruth is an attorney in private practice in Fairfield, Connecticut, who has taught Business Law and related courses at the University of New Haven College of Business. 
NOTES 